\title{
MODEL PEMBELAJARAN CONTEXTUAL TEACHING AND LEARNING DALAM PEMBELAJARAN MENULIS PERMULAAN DI KELAS II SEKOLAH DASAR
}

\author{
Windy Andriyanti ${ }^{1}$ ) \\ (SDN Sukapura Kec. Cibiru Kota Bandung)
}

\begin{abstract}
ABSTRAK
Pembelajaran menulis sering kali dianggap sebagai hal yang membosankan, karena prose spembelajarannya hanya dilakukan di dalamkelas. Hal ini merupakan salah satu penyebab rendahnya nilai belajar siswa. Untuk mengatasi permasalahan tersebut, peneliti menggunakan model pembelajaran $C T L$. Tujuan dari penelitian ini, yaitu untuk mengetahui proses pembelajaran, aktivitas, dan hasil belajar siswadengan menggunakan model pembelajaran CTL.. Penelitian ini menggunakan metode kualitatif dengan berfokuskan pada situasi kelas yang dikenal dengan sebutan penelitian tindakan kelas (classroom activity research). Berdasarkan hasil penelitian di lapangan, selama proses pembelajaran ditemukan beberapa hal penting. Siswa dapat melalui proses pembelajaran sesuai dengan tahap-tahap pembelajaran CTL. Siswa menjadi lebih semangat dan aktif, baik bersama kelompoknya ataupun secara individu. Hasil belajar siswa juga terus meningkat pada setiap siklusnya. Hal ini terlihat dari nilai rata-rata siswa mulai dari siklus I sampai siklus III yang mengalami kemajuan. Nilai rata-rata siswa siklus I yaitu 77,00, nilai rata-rata siklus II yaitu 84,76 , dan nilai rata-rata siklus III yaitu 96,30. Kesimpulan dari penelitian ini adalah bahwa pembelajaran menulis permulaan dengan menggunakan model pembelajaran CTL dapat meningkatkan proses pembelajaran, aktivitas, dan hasil belajar siswa.
\end{abstract}

\section{Kata kunci: Model CTL, Pembelajaran menulis}

\footnotetext{
${ }^{1}$ Penulis adalah SDN Sukapura Kec. Cibiru Kota Bandung
} 


\section{A. Pendahuluan}

Padaha kekatnya belajar bahasa adalah belajar berkomunikasi. Oleh karena itu pembelajaran Bahasa Indonesia diarahkan untuk meningkatkan kemampuan siswa dalam berkomunikasi baik secara lisan maupun secara tertulis. Pembelajaran Bahasa Indonesia di tingkat SD mencakup aspek menyimak, berbicara, membaca, dan menulis. Keempat aspek tersebut merupakan keterampilan berbahasa yang harus dikuasai dalam pembelajaran Bahasa Indonesia. Dalam pengembangan pembelajaran Bahasa Indonesia, tentu saja keempat keterampilan berbahasa ini tidak dapat dipisah-pisahkan, karena keempatnya merupakan catur tunggal yang saling berkaitan dan saling mengisi.

Hal ini sesuai dengan pendapat Tarigan (1994:1) bahwa setiap keterampilan berbahasa itu erat sekali hubungannya dengan ketiga keterampilan yang lainnya dengan cara beraneka ragam. Keempat keterampilan tersebut pada dasarnya merupakan satu kesatuan dan caturt unggal. Berdasarkan pendapat tersebut, dalam pembelajaran Bahasa Indonesia guru tidak boleh hanya mengajarkan salah satu keterampilan berbahasa saja tetapi harus dilatihkan secara bersama-sama.

Dari keempat keterampilan berbahasa, keterampilan menulis merupakan aspek terakhir yang dikuasai siswa setelah aspek-aspek yang lain. Menulis tampaknya sederhana namun mengandung makna yang sangat mendalam, karena keterampilan menulis sangat diperlukan untuk membangun kemampuan siswa dalam berkomunikasi dan memberikan pendapat serta ideidenya.

Berorientasi pada pendapat Piaget (Muchit, 2007:64), bahwa siswa yang berada pada rentang usia 7-11 tahun berada pada tahap operasionalkongkrit dimana pada tahap ini ditandai dengan adanya kemampuan menggunakan aturanaturan yang sistematis, logis dane mpiris. Tahap ini adalah tahap melakukan transformasi informasi kedalam dirinya sehingga tindakannya lebih efektif. Tahap ini diharapkan tidak ada proses coba-coba cenderung membuat kesalahan, tahap ini anak diasumsikan sudah dapat berpikir dengan menggunakan model "kemungkinan" dalam melakukan kegiatan tertentu.

Berdasarkan pendapat tersebut diharapkan permasalahan yang ditemui di lapangan, dapat segera ditangani dan siswa terbiasa mengaplikasikannya dalam setiap pembelajaran menulis. Agar dapat mewujudkan pembelajaran menulis yang menyenangkan, sudah barang tentu guru sebagai fasilitator pembelajaran dituntut untuk mencari prosedur pengembangan pembelajaran yang lebih baik, yaitu dengan menggunakan metode, teknik, media dans umber belajar yang sesuai dengan karakteristik siswa. Salah satu cara untuk meningkatkan keterampilan menulis dan memotivasi gairah belajar siswa dalam suasana yang menyenangkan adalah dengan menggunakan model pembelajaran yang menarik. Salah satu model yang dapat digunakan adalah model pembelajaran kontekstual yang dikenal dengan sebutan Contextual Teaching and Learning (CTL).

Suprijono (2014:79) pembelajaran kontekstual atau yang sering disebut dengan Contextual Teaching and Learning (CTL) merupakan konsep pembelajaran yang membantu siswa mengaitkan antara materi yang diajarkan dengan situasi dunia nyata dan mendorong siswa untuk membuat hubungan antara pengetahuan yang dimilikinya dengan penerapannya dalam kehidupan seharihari mereka sebagai anggota keluarga dan masyarakat. Adapun tujuan dari pembelajaran ini Contextual Teaching and Learning (CTL) ini adalah untuk membantu siswa dalam memahami makna 
bahan pelajaran yang mereka pelajari dengan cara menghubungkannya dengan konteks kehidupan mereka sendiri dalam lingkungan sosial dan budaya masyarakat. Teori konstruktivisme menjadi landasan utama pembelajaran Contextual Teaching and Learning. Hal ini dikarenakan pada pembelajaran Contextual Teaching and Learning, siswa mengkonstruksi pengetahuannya sendiri secara aktif. Pada konstruktivisme, pengetahuan bukanlan seperangkat fakta-fakta, konsep, atau kaidah yang siap untuk diambil dan diingat. Tetapi harus mengkonstruksi pengetahuan itu dan memberi makna melalui pengalaman nyata.

Terdapat beberapa prinsip dasar dalam pengembangan pembelajaran dengan menggunakan pembelajaran Contextual Teaching and Learning (CTL) ini diantaranya yaitu saling ketergantungan, diferensiasi, pengaturan diri, memusatkan pada bagaimna siswa mengerti makna dari apa dan manfaat apa yang mereka pelajari, merupakan pembelajaran yang autentik, mengembangkan level kognitif tingakat tinggi, memusatkan pada proses dan hasil (Suprijono, 2014:81-82).

Terdapat beberapa komponen pembelajaran CTL yang dapat dikembangkan dalam proses pembelajaran diantaranya, yaitu; 1) Konstruktivisme (constructivism), 2) Menemukan (Inquiry), 3) Bertanya (Questioning), 4) Masyarakat Belajar (Learning community), 5) Pemodelan (Modeling), 6) Refleksi (Reflection), 7) Penilaian yang Sebenarnya Assessment(Depdiknas, 2002:10).

Berdasarkan penjelasan di atas sangat jelas terlihat apabila model CTL merupakan salah satu model pembelajaran inovatif yang dapat digunakan dalam rangka menyelesaikan berbagai permasalahan pembelajaran, hal ini dikarenakan apabila dlihat dari fitur-fitur yang ada pada model CTL ini lebih banyak memberikan kesempatan pada siswa untuk mengembangkan pengetahuannya secara langsung lalu mengaitkannya dengan kehidupan seharihari. Hal tersebut dapat membuat proses pembelajaran lebih bermakna sehingga hasil belajar dapat bertahan lebih lama.

$$
\text { Berdasarkan paparan latang }
$$

belakang di atas maka peneliti tertarik untuk melakukan penelitian terkait dengan penerapan model CTL terhadap peningkatan kemampuan menulis siswa di SDN Sukapura Kec. Cibiru Kota Bandung mengingat rendahnya kemampuan menulis yang dimiliki oleh siswa.

\section{B.Metode Penelitian}

Metode penelitian yang digunakan dalam penelitian ini adalah penelitian tindakan kelas atau Classroom Action Research (CAR). Penelitian Tindakan Kelas adalah penelitian yang dilakukan oleh guru di dalam kelasnya sendiri melalui refleksi diri dengan tujuan untuk memperbaiki kinerja guru sehingga hasil belajar siswa menjadi meningkat. Penelitian tindakan kelas ini mengkombinasikan prosedur penelitian dengan tindakan subtantif, suatu tindakan yang dilakukan dalam disiplin inkuiri atau suatu usaha seseorang untuk memahami apa yang sedang terjadi sambil terlibat dalam sebuah proses perbaikan dan perubahan (Hopkins, 1933 :4 dalam Rochiati, 2008). Senada dengan penjelasan sebelumnya menurut (Dasna 2008:25) Penelitian Tindakan Kelas (PTK) merupakan ragam penelitian pembelajaran yang berkonteks kelas, dilaksanakan oleh guru untuk memecahkan masalah-masalah pembelajaran, memperbaiki mutu dan hasil pembelajaran, dan mencobakan halhalbaru dalam pembelajaran untuk peningkatan mutu dan hasilbelajar.

Melalui penelitian tindakan kelas ini peneliti dapat mengetahui dengan sistematis proses pembelajaran di dalam 
kelas sehingga dapat menganalisis berbagai macam kekurangan dan kendala selama pembelajaran berlangsung. Dengan analisis yang dilakuan pada setiap tindakan, peneliti dapat mengadakan perbaikan-perbaikan pada tindakan selanjutnya dengan membuat perencanaan yang matang untuk meningkatkan pemahaman siswa yang dijadikan objek penelitian.

Penelitian ini menekankan pada pembelajaran yang melatih siswa untuk meningkatkan kemampuan menulis yang merupakan salah satu kemampuan yang dimiliki siswa setelah mengikuti proses pembelajaran bahasa Indonesia. Adapun tempat penelitian pada penelitian ini yaitu di SDN Sukapura Kecamatan Cibiru Kota Bandung dengan subjek penelitiannya yaitu siswa siswi kelas II SDN Sukapura Kecamatan Cibiru Kota Bandung.

Penelitian Tindakan Kelas (PTK) ini dilaksanakan dalam 2 siklus, masingmasing siklus terdiri dari empat tahapan utama kegiatan yaitu: (a) perencanaan tindakan, (b) pelaksanaan tindakan, (c) observasi, dan (d) refleksi. Model pelaksanaan PTK ini menggunakan acuan model siklus PTK yang dikembangkan oleh Kemmis dan Mc Taggart. Secara rinci, tahapan-tahapan penelitian ini diuraikan sebagai berikut :

1. Perencanaan (planning)

Perencanaan dimulai dengan mengidentifikasi masalah yang terjadi di kelas II SDN Sukapura Kec. Cibiru Kota Bandung untuk diidentifikasi dan diperbaiki.

2. Pelaksanaan (action) dan Pengamatan Pelaksanaan merupakan tindakan yang harus dilakukan peneliti dalam upaya meningkatkan kemampuan menulis siswa. Pelaksanaan penelitian tindakan kelas ini menggunakan model CTL. Masing-masing tindakan membahas satu sub pokok bahasan.

3. Pengamatan atau observasi, dilakukan dengan tujuan untuk mengamati aktivitas siswa dalam proses pembelajaran dengan pendekatan realistik dan aktivitas guru selama proses pembelajaran.

4. Refleksi (reflection)

Refleksi merupakan sebuah kegiatan yang dilakukan untuk meninjau kembali apa yang sudah dilakukan oleh guru maupun siswa selama pembelajaran dalam suatu tindakan. Hasil refleksi tersebut digunakan untuk mengevaluasi dan memperbaiki kelebihan serta kekurangan pada pembelajaran di siklus sebelumnya.

Pada penelitian ini, rancangan awal akan dilakukan dua siklus, tetapi apabila hasil refleksi menghendaki tindakan lanjutan maka akan dilakukan perbaikan pada siklus selanjutnya sampai tujuan penelitian tercapai.

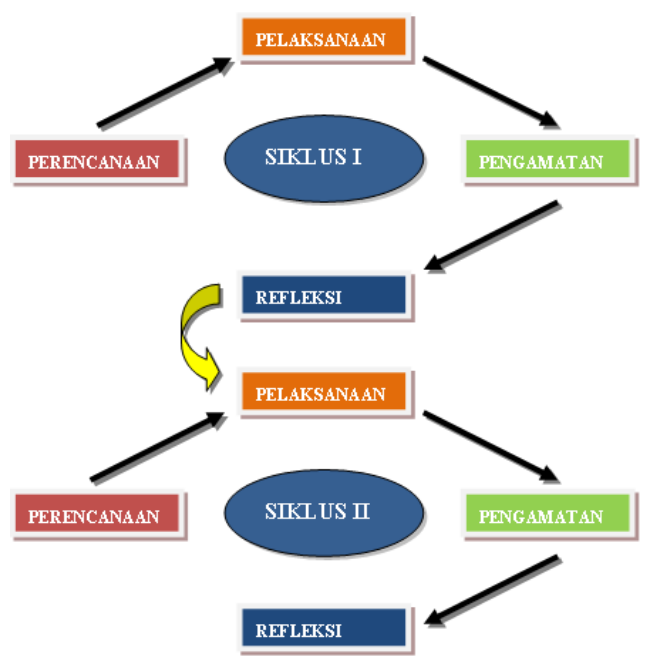

Gambar 1. Desain Penelitian Tindakan Kelas Kemmis dan Mc Taggart.

Instrument penelitian yang digunakan dan dikembangkan untuk pemerolehan data dalam pelaksanaan penelitian ini terdiri dari instrument tes dan non tes. Instrumen tes menggunakan butir soal untuk mengukur kemampuan menulis siswa, sedangkan instrumen tes yaitu dengan menggunakan lembar observasi. Lembar observasi ini digunakan untuk menganalisis temuan pada saat pembelajaran berlangsung 
secara lebih lengkap dan diisi oleh pengamat yang menjadi mitra peneliti pada setiap proses pembelajaran di setiap siklusnya.

\section{Hasil Penelitian}

Pada proses pembelajaran siklus I tindakan I berjalan dengan baik. Semua siswa dapat mengikuti tahapan pembelajaran. Siswa telah dapat membuat kalimat sederhana dari apa yang dilihatnya secara langsung. Siswa terlihat sangat antusias ketika sedang melakukan aktivitas, baik ketika sedang bekerja bersama kelompoknya maupun ketika mengerjakan tugas individu. Guru mengkondisikan siswa dengan penuh semangat. Cerita yang disampaikan guru pun sangat menarik perhatian siswa. Siswa merasa senang akan tema pembelajaran yang disampaikan. Siswa sangat menyukai belajar di luar kelas. Siswa merasa senang tampil di depan kelas. Begitu pula ketika siswa memberikan pendapat dan tanggapan atas pekerjaan kelompok yang lain. Mereka begitu bersemangat memberikan pendapat atas pekerjaan temannya. Siswa sepertinya mengerti apa yang telah dipelajarinya. Siswa juga senang akan rewards yang diberikan guru karena rewards tersebut berupa tambahan "bintang gemilang" dan dinilai tepat sasaran.

Keempat keterampilan berbahasa yang ingin dikembangkan oleh peneliti sudah terlihat selama proses pembelajaran. Guru terlihat mengembangkan kemampuan menyimak siswa melalui kegiatan menyimak prosedur pembelajaran dan menyimak presentasi yang dilakukan oleh siswa lain. Guru juga telah mengembangkan kemampuan berbicara siswa melalui kegiatan bertanya, menjawab pertanyaan, bercerita, dan mengemukakan pendapat. Kemampuan membaca siswa juga terlihat melalui kegiatan membaca nyaring kalimat yang telah ditulis sebelumnya oleh siswa. Begitu pula kemampuan menulis siswa dikembangkan oleh guru melalui kegiatan menulis nama tempat umum yang ditemui dan menulis kalimat sederhana dari nama tempat umum yang ditemui, baik secara berkelompok maupun secara individu.Namun demikian masih terdapat kekurangan yang terjadi selama proses pembelajaran. Menurut observer guru tidak memunculkan kompetensi yang harus dicapai siswa dalam pembelajaran. Guru kurang menekankan pemahaman tentang materi yang dibahas. Guru juga kurang memunculkan penguatan terhadap perbaikan-perbaikan. Siswa kurang memperhatikan tata cara menjawab pertanyaan dan mengemukakan pendapat. Siswa terlihat masih takut serta malu-malu dalam mengemukakan pendapat dan menjawab pertanyaan. Beberapa siswa cenderung mempermainkan atau mengolok-olok pekerjaan temannya. Ada satu orang siswa yang tidak mau menyelesaikan tugasnya. Seorang siswa lagi berlari jauh dari kelompoknya karena ingin mencari tempat umum yang berbeda dari kelompok yang lain. Ada tiga orang siswa yang lupa cara penulisan beberapa huruf kapital.

Pada proses pembelajaran siklus II tindakan Isudah terdapat banyak perbaikan dari tindakan sebelumnya. Guru menyampaikan kompetensi secara lengkap dan jelas. Walaupun materi inti pembelajaran merupakan pengulangan dari pertemuan sebelumnya, namun karena dikemas dengan tema yang berbeda siswa tetap antusias mengikuti proses pembelajaran.Pada proses pembelajaran pada siklus II tindakan I ini terlihat telah ada perbaikan.

Pada tindakan ini telah terlihat adanya perkembangan dari segi pengembangan keterampilan berbahasa. Perkembangan ini terlihat dari keterampilan berbicara siswa, yaitu ketika siswa menjawab pertanyaan dan mengemukakan pendapat. Siswa sudah 
tidak merasa takut dan malu-malu lagi. Hampir semua siswa mau menjawab dan mengemukakan pendapatnya. Tata cara yang digunakan siswa dalam menjawab dan mengemukakan pendapat pun sudah lebih baik daripada pertemuan sebelumnya. Apalagi dengan keterampilan menulisnya. Siswa terlihat telah memiliki kemampuan dan kepercayaan diri yang lebih dalam menulis kalimat yang dibuatnya. Hal ini terlihat dari kecepatan menulis kalimat dan kualitas hasil tulisan. Sedangkan untuk keterampilan menyimak dan membaca hasilnya hampir sama dengan pertemuan sebelumnya.

Pada proses pembelajaran siklus III tindakan I terlihat banyak peningkatan baik dari segi proses pembelajaran, aktivitas siswa maupun hasil pembelajaran.Pada kegiatan awal, ketika guru mengkondisikan siswa, siswa langsung duduk dengan tertib. Siswa antusias mendengarkan cerita guru. Siswa bersorak dan bertepuk tangan ketika guru menyampaikan tema dan tujuan pembelajaran. Siswa mengangkat tangannya terlebih dahulu ketika ingin menjawab pertanyaan yang diajukan guru. Siswa menyimak prosedur pembelajaran yang disampaikan guru. Ketika guru mengelompokkan siswa, siswa langsung berkumpul bersama kelompoknya. Dalam pengembangan kemampuan berbahasanya, siswa juga telah memperlihatkan perkembangan yang baik. Siswa berusaha untuk mengembangkan dan merealisasikan berbagai keterampilan berbahasa selama proses pembelajaran berlangsung. Siswa telah dapat menyimak petunjuk dan penyampaian guru dengan baik, sehingga proses pembelajaran dapat berjalan dengan lancar. Dalam keterampilan berbicaranya, siswa telah mampu menerapkan tata cara bertanya dan menjawab dengan baik. Tidak ditemui lagi siswa yang berteriak secara serempak ataupun malu ketika akan mengemukakan pendapatnya. Pada keterampilan menulis, hampir semua siswa dapat menulis dengan baik sesuai dengan aturan yang telah dibakukan. Begitu pula dengan keterampilan membacanya, siswa dapat membaca nyaring kalimat dengan memperhatikan penggunaan lafal dan intonasi.

Melihat hasil deskripsi, analisis, dan refleksi selama proses pembelajaran darisiklus I tindakan I sampai siklus III tindakan I, dapat dikatakan proses pembelajaran menulis kalimat permulaan dengan menggunakan model pembelajaran $C T L$ telah berhasil. Hal ini dapat terlihat dari adanya peningkatan kualitas dan kuantitas, baik selama proses pembelajaran, aktivitas siswa maupun dalam hasil belajarnya.Berikut ini merupakan tabel rekapitulasi nilai evaluasi hasil pada setiap siklus:

Tabel 1. Perolehan Nilai Evaluasi Hasil Individu Setiap Siklus

\begin{tabular}{|c|c|c|c|c|}
\hline \multirow{2}{*}{ No } & \multirow{2}{*}{ Nama } & \multicolumn{3}{|c|}{ Siklus } \\
\cline { 3 - 5 } & & I & II & III \\
\hline 1 & $\mathrm{X} 1$ & 88,9 & 88,9 & 100 \\
\hline 2 & $\mathrm{X} 2$ & 88,9 & 88,9 & 88,9 \\
\hline 3 & $\mathrm{X} 3$ & 77,7 & 77,7 & 100 \\
\hline 4 & $\mathrm{X} 4$ & 55,5 & 77,7 & 88,9 \\
\hline 5 & $\mathrm{X} 5$ & - & 77,7 & 100 \\
\hline 6 & $\mathrm{X} 6$ & 55,5 & 77,7 & 100 \\
\hline 7 & $\mathrm{X} 7$ & - & 100 & 100 \\
\hline
\end{tabular}




\begin{tabular}{|c|c|c|c|c|}
\hline \multirow{2}{*}{ No } & Nama & \multicolumn{3}{|c|}{ Siklus } \\
\cline { 3 - 5 } & & I & II & III \\
\hline 8 & X8 & 66,7 & 77,7 & 100 \\
\hline 9 & $\mathrm{X} 9$ & 55,5 & 88,9 & 100 \\
\hline 10 & $\mathrm{X} 10$ & - & 88,9 & 100 \\
\hline 11 & $\mathrm{X} 11$ & 77,7 & 77,7 & 88,9 \\
\hline 12 & $\mathrm{X} 12$ & - & 100 & 100 \\
\hline 13 & $\mathrm{X} 13$ & 88,9 & 88,9 & 100 \\
\hline 14 & $\mathrm{X} 14$ & - & 77,7 & 100 \\
\hline 15 & $\mathrm{X} 15$ & 77,7 & 88,9 & 88,9 \\
\hline 16 & $\mathrm{X} 16$ & - & 77,7 & 88,9 \\
\hline 17 & $\mathrm{X} 17$ & 88,9 & - & 100 \\
\hline 18 & $\mathrm{X} 18$ & 100 & - & 100 \\
\hline 19 & $\mathrm{X} 19$ & 55,5 & 77,7 & 88,9 \\
\hline 20 & $\mathrm{X} 20$ & 88,9 & 88,9 & 100 \\
\hline 21 & $\mathrm{X} 21$ & 88,9 & 88,9 & 88,9 \\
\hline & & & & \\
\hline & Jumlah & $\mathbf{1 . 1 5 5 , 2}$ & $\mathbf{1 . 6 1 0 , 5}$ & $\mathbf{2 . 0 2 2 , 3}$ \\
\hline & Rata-rata & $\mathbf{7 7 , 0 0}$ & $\mathbf{8 4 , 7 6}$ & $\mathbf{9 6 , 3 0}$ \\
\hline
\end{tabular}

Tabel 2.

Perolehan Nilai Evaluasi Hasil Kelompok Setiap Siklus

\begin{tabular}{|c|c|c|c|c|}
\hline \multirow{2}{*}{ No } & \multirow{2}{*}{ Kelompok } & \multicolumn{3}{|c|}{ Siklus } \\
\cline { 3 - 5 } & & I & II & III \\
\hline 1 & I & 44,4 & 77,7 & 88,9 \\
\hline 2 & II & 55,5 & 88,9 & 100 \\
\hline 3 & III & 66,7 & 88,9 & 100 \\
\hline 4 & IV & 88,9 & 100 & 100 \\
\hline 5 & V & 100 & 100 & 100 \\
\hline & & & & \\
\hline & Jumlah & $\mathbf{3 5 5 , 5}$ & $\mathbf{4 5 5 , 5}$ & $\mathbf{4 8 8 , 9}$ \\
\hline & Rata-rata & $\mathbf{7 1 , 1}$ & $\mathbf{9 1 , 1}$ & $\mathbf{9 7 , 7 8}$ \\
\hline
\end{tabular}




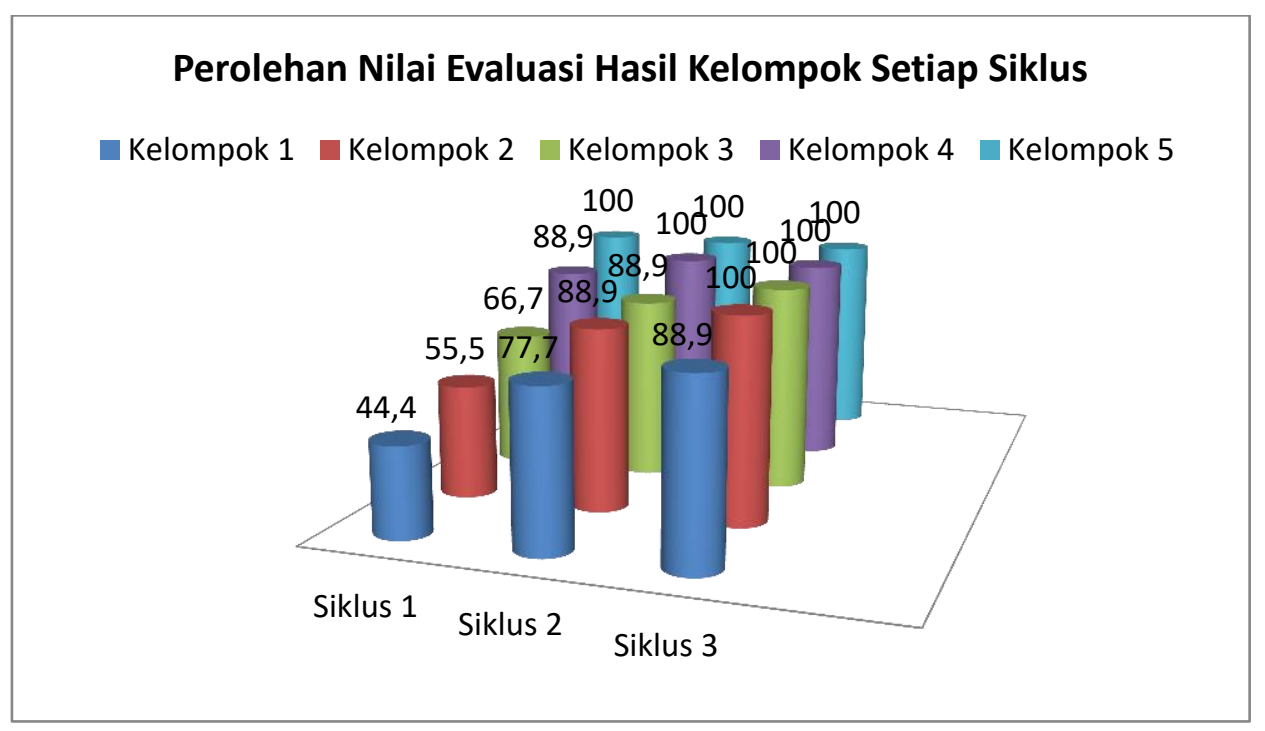

Grafik 1.

Perolehan Nilai Evaluasi Hasil Kelompok Setiap Siklus

Berdasarkan table dan grafik di atas, terlihat bahwa perolehan nilai ratarata dari siklus I kesiklus II baik untuk evaluasi individu ataupun kelompok mengalami peningkatan yang cukup signifikan. Pada nilai evaluasi individu terdapat lima orang siswa yang mendapat nilai 55,5, namun pada siklus II, siswa tersebut mendapatkan nilai yang lebih baik lagi. Begitu pula dengan evaluasi kelompok, ada kelompok yang mendapatkan nilai 44,4dan 55,5. Pada siklus II, nilai kelompok tersebut dapat meningkat menjadi lebh baik.Pada siklus III terdapat peningkatan kembali. Pada evaluasi individu, tidak ada siswa yang mendapatkan nilai kurang baik. Semua siswa mendapatkan nilai antara 88,9 sampai 100, begitu pula dengan hasil evaluasi kelompoknya, untuk evaluasi kelompok, siklus I tindakan I mendapatkan rata-rata nilai 71,10 , siklus II tindakan I mendapatkan rata-rata 91,10, dan rata-rata nilaisiklus III tindakan I mendapatkan rata-rata nilai 97,78. Pada evaluasi individu, nilai rata-rata sikus I tindakan I adalah 77,00, siklus II tindakan I menjadi 84,76, pada siklus III tindakan I akhirnya menjadi 96,30.

\section{Pembahasan}

Belajar akan lebih bermakna jika siswa mengalami apa yang dipelajarinya, bukan sekedar mengetahuinya. CTL merupakan konsep belajar yang mengaitkan materi yang diajarkan dengan situasi di dunia nyata siswa dan mendorong siswa menghubungkan pengetahuan yang dimilikinya dengan penerapannya dalam kehidupan mereka sehari-hari sebagai anggota keluarga dan masyarakat. Penyajian materi pada siklus I adalah menulis kalimat permulaan memperhatikan penggunaan huruf kapital dan tanda baca titik dengan tema tempat umum. Materi siklus II adalah menulis kalimat permulaan memperhatikan penggunaan huruf kapital dan tanda baca titik dengan tema makanan. Sedangkan materi pada siklus III adalah menulis kalimat permulaan memperhatikan penggunaan huruf kapital dan tanda baca titik dengan tema lingkungan.

Pada setiap siklus peneliti menggunakan lingkungan di sekitar siswa untuk dijadikan sumber belajarnya dan contoh penulisan huruf kapital yang sudah dibakukan sebagai media pembelajarannya. Siswa harus mampu membuat kalimat sederhana sesuai dengan 
tema yang ditentukan, kemudian menuliskannya menggunakan huruf kapital dan tanda baca dengan tepat. Siswa bekerja dengan kelompoknya, kemudian diaplikasikan oleh individunya masing-masing setelah melalui kegiatan presentasi dan diskusi. Penilaian tidak hanya pada hasil tulisan, akan tetapi pada proses pembelajarannya merupakan bagian evaluasi yang paling penting. Pada akhir pembelajaran siswa beersama guru selalu mengadakan refeksi pembelajaran untuk mengetahui kekurangan dan kelebihan yang ditemukan selama proses pembelajaran berlangsung. Pernyataan ini sesuai dengan komponen pembelajaran CTL, yaitu; 1) Konstruktivisme (constructivism), 2) Menemukan (Inquiry), 3) Bertanya (Questioning), 4) Masyarakat Belajar (Learning community), 5) Pemodelan (Modeling), 6) Refleksi (Reflection), 7) Penilaian yang Sebenarnya (Authentic Assessment.(Depdiknas, 2002:10).

Pada proses pembelajarannya, guru memulai dengan mendorong agar siswa mau mengemukakan pengetahuan awal tentang materi yang akan dibahas, memberi kesempatan kepada siswa untuk menyelidiki dan menemukan konsep melalui pengumpulan, pengorganisasian, dan penginterprestasian data, menjelaskan dan memberikan solusi berdasarkan hasil observasinya, serta memotivasi siswa untuk membuat keputusan, menggunakan pengetahuan dan keterampilan, berbagai informasi dan gagasan, mengajukan pertanyaan lanjutan, serta mengajukan saran baik secara individu maupun secara berkelompok yang berhubungan dengan pemecahan masalah. Pernyataan tersebut sesuai dengan langkah-langkah atau tahapan model pembelajaran $C T L$, yang meliputi tahap invitasi, tahap eksplorasi, tahap penjelasan dan solusi, serta tahap aplikasi. (Sutardi dan Sudirjo, 2008: 106).

\section{E.Simpulan}

Contextual Teaching and Learning (CTL) atau pembelajaran kontekstual merupakan konsep belajar yang mengaitkan materi yang diajarkan dengan realitas dunia siswa sehingga siswa dapat membuat hubungan antara pengetahuan yang dimiliki dengan penerapannya. Pembelajaran bahasa bukan hanya memberikan pemahaman berupa definisi melainkan siswa dituntut untuk dapat menemukan pengetahuannya sendiri. Guru harus memiliki strategi yang memacu siswa untuk dapat berpikir kritis dan kreatif.Implementasi CTL pada pembelajaran membaca, berbicara, menulis, dan mendengarkan dapat membuat pembelajaran lebih kreatif, dan menuntut siswa untuk lebih berpikir kritis. Artinya siswa dipacu untuk menghubungkan antara materi yang diajarkan dengan kehidupan sehari-hari.

\section{F. Daftar Rujukan}

Baharudindan Wahyuni, E. N. (2008).Teori

Belajar\&Pembelajaran. Jogyakarta: Ar-ruzz Media.

Bakar, Z., Ernalis, dan Harun, A., H. (2007). Pendidikan Bahasa dan Sastra Indonesia di KelasRendah. Bandung: UPI KampusCibiru.

Departemen Pendidikan Nasional. (2002). Pendekatan Kontekstual. Jakarta: Depdiknas.

DepartemenPendidikan Nasional. (2006). Standar Kompetensi dan Kompetensi Dasar. Jakarta: Depdiknas.

Dewi, E. (2008). Pendekatan CTL untuk Meningkatkan Aktivitas Siswa dalam Pembelajaran Menulis Karangan Deskripsi. Skripsi Sarjana Pendidikan. 
pada FIP UPI Bandung: tidakditerbitkan.

Muchith, S. (2008). Pembelajaran Kontekstual. Semarang: Rasail.

Nurgiantoro, B. (2001). Penilaian dalam Pembelajaran Bahasa da Sastra Indonesia. Yogyakarta: BPFE.

Purwaningtyas, S. (2008). Pengaruh Pendekatan CTL terhadap Keterampilan

Menulis Karangan Deskripsi Ditinjaudari Motivasi Belajar Siswa. Skripsi

Sarjana Pendidikan pada FIP UPI Bandung: tidakditerbitkan.
Resmini, N., Churiyah, Y., danSundori, N. (2006). Membacadan Menulis di SD :Teoridan Pengajarannya. Bandung: UPI Press.

Sugiyono.(2007). Penelitian Tindakan Kelas. Jakarta: Erlangga.

Suprijono, A. (2014). Cooperative learning teori dan aplikasi PAIKEM. Yogyakarta: Pustaka Pelajar.

Tarigan, HG. (1994). Menulis sebagai Suatu Keterampilan Berbahasa. Bandung: Angkasa. 